\title{
DESAIN BADAN PERADILAN KHUSUS PEMILIHAN KEPALA DAERAH DALAM RANGKA MENGHADAPI PEMILIHAN KEPALA DAERAH SERENTAK NASIONAL TAHUN 2024
}

\author{
Ispan Diar Fauzi \\ Pascasarjana IImu Hukum Universitas Suryakancana \\ Ispandiaridf@gmail.com
}

\begin{abstract}
Abstrak
This study aims to answer the problems, the formulation and design of the special courts election and the excellences of the special courts election. This was conducted using legal-normative research through conceptual approach. In this study, special court local election are designed as a permanent adjudication court. The judicial jurisdiction under the Supreme Court includes the High Court for the special court of election of the Governor and the District Court for the special court of election of the Regent / Mayor. Special court designed has three assemblies, state administrative dispute assemblies, criminal act assemblies and dispute of electoral results assemblies. The authority of the special court election is to examine and decide all disputes during the election process. For the composition of the judges will be filled by career judges and ad hoc judges. Special court electoral in each jurisdiction are designed as the first and final judicial institutions whose decisions are final and binding. One of the advantage of special court election is the special court of local elections which provides for the settle of all disputes during the election process.
\end{abstract}

Keywords: Disputes, Local Electons, Special Court, Special Court Election.

\begin{abstract}
Abstrak
Penelitian ini bertujuan untuk menjawab permasalahan terkait formulasi dan desain kelembagaan badan peradilan khusus Pilkada dan membahas mengenai keunggulankeunggulan badan peradilan khusus Pilkada. Penelitian ini dilakukan dengan metode yuridis normatif melalui pendekatan konsep (conceptual approach). Pada penelitian
\end{abstract}


ini pengadilan khusus Pilkada didesain sebagai lembaga adjudikasi permanen, berkedudukan dibawah Mahkamah Agung yang yurisdiksi peradilannya meliputi: Pengadilan Tinggi untuk pengadilan khusus pemilihan Gubernur dan Pengadilan Negeri untuk pengadilan khusus pemilihan Bupati/Wali Kota. Kewenangan pengadilan khusus Pilkada tersebut yaitu memeriksa, mengadili dan memutus seluruh sengketa yang timbul selama proses Pilkada. Pengadilan khusus Pilkada nantinya memiliki tiga majelis, yaitu majelis khusus sengketa tata usaha negara, majelis khusus tindak pidana dan majelis khusus perselisihan hasil pemilihan. Terkait komposisi hakim akan diisi oleh hakim karir dan hakim ad hoc yang menguasai hukum kepemiluan. Pengadilan khusus Pilkada disetiap yurisdiksinya didesain sebagai lembaga peradilan pertama dan terakhir yang putusannya bersifat final dan mengikat. Salah satu keunggulan yang dimiliki oleh peradilan khusus Pilkada ini adalah mempunyai kompetensi absolut untuk menyatuatapkan penanganan seluruh sengketa yang timbul selama proses penyelenggaraan Pilkada.

Kata Kunci: Sengketa, Pilkada, Peradilan Khusus, Pengadilan Khusus Pilkada.

\section{Pendahuluan}

Pemilihan kepala daerah (Pilkada) secara langsung (direct local democracy) menjadi salah satu bagian terpenting dalam proses reformasi dan pendewasaan demokrasi di Indonesia. Pilkada sebagai salah satu bagian penyelenggaraan pemerintahan daerah telah diatur dalam undang-undang tersendiri, yang sebelumnya menjadi domain undang-undang pemerintahan daerah. Pengaturan Pilkada pertama kali diatur dalam Undang-Undang Nomor 22 Tahun 2014 Tentang Pemilihan Gubernur, Bupati, dan Walikota.

Undang-undang Pilkada ini merupakan salah satu undang-undang yang sering mengalami perubahan. Sejak pertama kali diundangkan Penulis mencatat setidaknya ada empat kali perubahan, hingga pada akhirnya Presiden mengesahkan Undang-Undang Nomor 10 Tahun 2016 tentang Perubahan Kedua Atas Undang-Undang Nomor 1
Tahun 2015 Tentang Penetapan Peraturan Pemerintah Pengganti Undang-Undang Nomor 1 Tahun 2014 Tentang Pemilihan Gubernur, Bupati, dan Walikota Menjadi Undang-Undang (selanjutnya disebut UU Pilkada).

Substansi perubahan UU Pilkada yang mendasar dan esensial salah satunya adalah penyelenggaraan Pilkada secara serentak di seluruh wilayah Indonesia. Berdasarkan UU Pilkada, Pilkada serentak nasional akan dilaksanakan pada tahun 2024. Dengan Diselenggarakannya Pilkada secara serentak nasional, hal penting yang harus jadi perhatian adalah ekses klasik dari setiap penyelenggaraan Pilkada, yaitu munculnya sengketa pemilihan atau kasus hukum (legal case) baik itu tindak pidana pemilihan, sengketa tata usaha negara pemilihan, pelanggaran administrasi pemilihan maupun sengketa perselisihan hasil pemilihan (PHP).

Saat ini proses penyelesaian sengketa Pilkada seperti tindak pidana pemilihan, 
sengketa tata usaha negara pemilihan dan perselisihan hasil pemilihan kepala daerah, dilaksanakan oleh badan peradilan yang terpisah. Tindak pidana pemilihan diadili oleh majelis khusus tindak pidana pada peradilan umum, sengketa tata usaha negara diadili oleh majelis khsusus tata usaha negara pada peradilan Tata Usaha Negara dan sengketa perselisihan hasil pemilihan diselesaikan melalui Mahkamah Konstitusi.

Tantangan kemudian jika tetap mempertahankan desain seperti yang telah dikemukakan diatas, adalah ketepatan waktu penyelesaian perkara, terlebih dengan diserentakannya Pilkada maka kasus-kasus yang muncul akan lebih banyak, konsekuensi logisnya dibutuhkan waktu yang cukup panjang untuk menyelesaikan setiap kasus yang muncul dalam tahapan Pilkada.

Selain itu sentralisasi penyelesaian sengketa hasil pemilihan lewat Mahkamah Konstitusi (MK), akan menyebabkan perkara yang di tangani oleh MK semakin banyak, dengan keterbatasan hakim konstitusi yang hanya berjumlah sembilan orang, dan juga tenggat waktu yang relatif singkat, tentunya mahkamah akan kesulitan menyelesaikan setiap perkara yang ditangani.

Selain singkatnya waktu tahapan Pilkada, penyelesaian sengketa hasil pemilihan lewat MK juga sesungguhnya kontraproduktif dengan putusan MK Nomor 97/PUU-XI/2013 yang menghapus kewenangan $M K$ untuk menangani sengketa hasil Pilkada. ${ }^{1}$

1 Mahkamah berpendapat dalam putusannya bahwa dalam memahami kewenangan Mahkamah Konstitusi yang ditentukan
Didasarkan pada kenyataankenyataan diatas maka dibutuhkan suatu badan peradilan khusus yang dapat mengintegrasikan (menyatuatapkan) penyelesaian kasus pidana pemilihan, sengketa tata usaha negara, dan sengketa hasil pemilihan. Badan peradilan khusus tersebut nantinya tidak hanya menyelesaikan kasus dengan tepat waktu, efektif dan efisien tetapi juga akan mengahadirkan keadilan (electoral justice) dalam setiap putusannya.

Pembentukan badan peradilan khusus Pilkada sesungguhnya adalah perintah UU Pilkada (delegatie provisio), sebagaimana diatur dalam Pasal 157 ayat (1) UU Pilkada. Merujuk ketentuan pada pasal a quo, maka ada kepentingan hukum (legal importance) untuk membentuk badan peradilan khusus Pilkada. Meskipun dalam konstruksi pasal tersebut badan peradilan khusus dibentuk hanya untuk menangani perkara perselisihan hasil pemilihan, namun dalam penelitian ini Penulis akan mencoba menawarkan

dalam Pasal 24C ayat (1) UUD NRI 1945 harus kembali melihat makna teks, original intent, makna gramatika yang komprehensif terhadap UUD NRI 1945. Oleh karena itu, pemilihan umum menurut Pasal $22 \mathrm{E}$ UUD NRI 1945 haruslah dimaknai secara limitatif, yaitu pemilihan umum yang diselenggarakan untuk memilih presiden dan wakil presiden, anggota DPR, DPD serta DPRD yang dilaksanakan setiap lima tahun sekali. Dengan demikian penambahan kewenangan Mahkamah Konstitusi untuk mengadili perkara perselisihan hasil Pilkada dengan memperluas makna pemilihan umum yang diatur dalam Pasal 22E UUD NRI 1945 adalah inkonstitusional. Namun pandangan mahkamah konstitusi tersebut tidak bulat ada tiga hakim konstitusi yang berbeda pendapat (dissenting opinion). 
konsep badan peradilan khusus yang tidak hanya menangani perkara perselisihan hasil pemilihan tetapi juga mempunyai kompetensi absolut untuk menyelesaikan tindak pidana pemilihan dan sengketa tata usaha negara pemilihan.

\section{Metode Penelitian}

Dalam penelitian ini Penulis meggunakan metode penelitian yuridis normatif, yaitu penelitian hukum yang dilakukan dengan cara meneliti bahan pustaka (penelitian kepustakaan) atau suatu penelitian yang dilakukan terhadap data sekunder. (Soerjono Soekanto dan Sri Mamudji, 2003).

Metode pendekatan yang digunakan adalah pendekatan konsep (conceptual approach). Pendekatan konsep (conceptual approach) beranjak dari pandanganpandangan dan doktrin-doktrin yang berkembang didalam ilmu hukum. (Peter Mahmud Marzuki, 2010).

Pendekatan konsep (conceptual approach) berperan penting ketika permasalahan yang harus dijawab tidak mempunyai pijakan yuridis yang sempurna. Ketika Penulis dihadapkan pada kondisi ketidaksempurnaan legalitas, megharuskan mengangkat ke atas abstraksi suatu konsep. Selain itu pendekatan konsep (conceptual approach) ini dimaksudkan untuk mengupas secara komprehensif tentang desain badan peradilan khusus Pilkada.

\section{Perspektif Teori}

\subsection{Pemilihan Kepala Daerah}

Undang-Undang Dasar Negara Republik Indonesia (UUD NRI) 1945 telah menyatakan bahwa Indonesia merupakan negara hukum (vide Pasal 1 ayat (3)).
Selain sebagai negara hukum, pada Pasal 1 ayat (2) UUD NRI 1945 juga dijelaskan bahwa Indonesia merupakan negara yang berkedaulatan rakyat (demokratis).

Mengkombinasikan kedua pasal dalam konstitusi tersebut dapat dimaknai bahwa negara hukum Indonesia haruslah dijalankan melalui mekanisme kontrol masyarakat, dimana rakyat memegang peranan penting dalam proses penyelenggaraan negara, namun demikian kontrol masyarakat tersebut haruslah sesuai dengan norma hukum yang telah ditentukan.

Salah satu implementasi konsep Negara Hukum Indonesia yang demokratis, pada Pasal 18 ayat (4) UUD NRI 1945 telah memerintahkan untuk diselenggarakan pemilihan Gubernur, Bupati, Walikota (selanjutnya disebut Pilkada) secara demokratis.

Pilkada menurut Joko J. Prihatmoko (2005) diartikan sebagai penyeleksian rakyat terhadap tokoh-tokoh yang mencalonkan diri sebagai kepala daerah, baik Gubernur/Wakil Gubernur maupun Bupati/Wakil Bupati atau Walikota/Wakil Walikota.

Sedangkan dalam Pasal 1 angka 1 UU Pilkada disebutkan bahwa Pilkada adalah Pemilihan Gubernur dan Wakil Gubernur, Bupati dan Wakil Bupati, serta Walikota dan Wakil Walikota sebagai pelaksanaan kedaulatan rakyat di wilayah provinsi dan kabupaten/kota untuk memilih Gubernur dan Wakil Gubernur, Bupati dan Wakil Bupati, serta Walikota dan Wakil Walikota secara langsung dan demokratis.

Sementara itu Siti Zuhro mengatakan bahwa:

\footnotetext{
"Pilkada merupakan bagian dari proses penguatan dan pendalaman
} 
demokrasi (deepening democracy) serta upaya mewujudkan tata pemerintahan yang efektif di tingkat lokal. Selain itu, pelaksanaan Pilkada pada dasarnya juga merupakan tindak lanjut realisasi prinsip-prinsip demokrasi yang meliputi jaminan atas prinsip-prinsip kebebasan individu dan persamaan khususnya dalam hak politik" (Zuhro, 2012, hlm. 30-31).

Membahas Pilkada maka tidak dapat dipisahkan dari konteks dan realitas perkembangan demokrasi lokal di Indonesia. Memahami demokrasi lokal memang tidak dapat memisahkan diri dari perbincangan tentang kebijakan desentralisasi. Mengingat kebijakan ini merupakan pintu awal bagi terciptanya demokrasi lokal. Bahkan sejumlah ahli meyakini bahwa tujuan yang sesungguhnya dari desentralisasi tidak lain adalah menumbuhkan demokrasi lokal. (Suyanto, 2016).

Keyakinan bahwa dengan adanya desentralisasi akan menumbuhkan demokrasi lokal didukung oleh pernyataan Robert Putnam (dalam Suyanto, 2016, hlm. 226), yang menyatakan:

"desentralisasi akan menumbuhkan partisipasi dan tradisi kewargaan di tingkat lokal. Partisipasi demokratis warga telah melahirkan komitmen warga yang luas maupun hubunganhubungan horisontal: kepercayaan (trust), toleransi, kerjasama, dan solidaritas yang membentuk komunitas sipil (civic community).

Demokrasi lokal merupakan bagian dari subsistem politik suatu negara yang derajat pengaruhnya berada dalam koridor pemerintahan daerah. Di Indonesia demokrasi lokal merupakan subsistem dari demokrasi yang memberikan peluang bagi pemerintahan daerah dalam mengembangkan kehidupan hubungan pemerintahan daerah dengan rakyat di lingkungannya.

\subsection{Peradilan Khusus dalam Sistem Hukum Indonesia}

Konsep peradilan khusus (pengadilan khusus) dalam sistem hukum nasional Indonesia bukanlah instrumen peradilan yang baru. Berdasarkan catatan sejarah, pernah dibentuk atau diakui beberapa pengadilan khusus yang memeriksa dan memutus perkara atau subyek tertentu, misalnya pada awal kemerdekaan dikenal pengadilan Swapraja dan Pengadilan Adat. (Hamdan Zoelva, 2013).

Istilah pengadilan khusus secara yuridis (de jure) pertama kali termaktub dalam Undang-Undang Nomor 19 Tahun 1964 Tentang Ketentuan-Ketentuan Pokok Kekuasaan Kehakiman. Penjelasan Pasal 7 ayat (1) UU a quo membagi peradilan kedalam tiga macam, yaitu Peradilan Umum, Peradilan Khusus dan Peradilan Tata Usaha Negara.

Saat ini keberadaan Pengadilan khusus secara an sich diatur dalam Pasal 1 angka 8 Undang-Undang Nomor 48 Tahun 2009 Tentang Kekuasaan Kehakiman, pada Pasal a quo disebutkan bahwa:

"Pengadilan Khusus adalah pengadilan yang mempunyai kewenangan untuk memeriksa, mengadili dan memutus perkara tertentu yang hanya dapat dibentuk dalam salah satu lingkungan badan peradilan yang berada di bawah Mahkamah Agung yang diatur dalam undang-undang".

Lebih lanjut Pasal 27 ayat (1) Undang- 
Undang Nomor 48 Tahun 2009 tentang Kekuasaan Kehakiman menentukan bahwa:

"Pengadilan khusus hanya dapat dibentuk dalam salah satu lingkungan peradilan yang berada di bawah Mahkamah Agung".

Menurut Refly Harun (2016) dalam kekuasaan kehakiman, sampai saat ini, setidaknya ada delapan pengadilan khusus yang berada di bawah lingkungan peradilan umum, agama dan tata usaha negara, yaitu : pengadilan anak, pengadilan niaga, pengadilan hak asasi manusia, pengadilan tindak pidana korupsi, pengadilan hubungan industrial, pengadilan perikanan, mahkamah syariah, pengadilan pajak. Enam jenis pengadilan pertama merupakan pengadilan yang berada dalam lingkungan peradilan umum, sedangkan dua jenis pengadilan yang terakhir masing-masing berada dalam lingkungan peradilan agama dan peradilan tata usaha negara.

\section{Hasil dan Pembahasan}

\subsection{Desain Kelembagaan Badan Peradilan Khusus Pilkada}

Politik hukum kebijakan pembentukan pengadilan khusus Pemilihan Kepala Daerah (Pilkada) merupakan pilihan para pembentuk undang-undang melalui pengesahan Undang-Undang Nomor 10 Tahun 2016 Tentang Perubahan Kedua Atas Undang-Undang Nomor 1 Tahun 2015 Tentang Penetapan Peraturan Pemerintah Pengganti Undang-Undang Nomor 1 Tahun 2014 Tentang Pemilihan Gubernur, Bupati, dan Walikota Menjadi Undang-Undang (Selanjutnya disebut UU Pilkada).
Pasal 157 ayat (1) UU Pilkada menyebutkan:

"Perkara perselisihan hasil pemilihan diperiksa dan diadili oleh badan peradilan khusus". ayat (2) : "Badan peradilan khusus sebagaimana dimaksud pada ayat (1) dibentuk sebelum pelaksanaan pemilihan serentak nasional".

Membaca seluruh substansi UU Pilkada dan rumusan pasal a quo, tidak ditemukan rumusan pasti bagaimana kedudukan dan kewenangan yang dimiliki oleh pengadilan khusus Pilkada, selain itu apakah desain kelembagaannya akan diletakkan di salah satu badan peradilan dibawah Mahkamah Agung atau dibentuk lembaga lain diluar lingkungan peradilan tersebut sebagai quasi peradilan. Ketidakjelasan lainnya dalam UU Pilkada adalah apakah yurisdiksi peradilannya berada di tingkat pusat, provinsi, atau kabupaten/ kota.

Sebagai suatu ius constituendum, dibawah akan dikonstruksikan desain pengadilan khusus Pilkada. Ada 2 (dua) aspek yang harus diperhatikan dan dikaji secara komprehensif dalam mendesain pengadilan khusus Pilkada, yaitu :

\section{Desain Pengaturan dan Kelembagaan}

Ketentuan yuridis terkait pembentukan pengadilan khusus dapat dijumpai dalam Undang-Undang Nomor 48 Tahun 2009 Tentang Kekuasaan Kehakiman (selanjutnya disebut UU Kekuasaan Kehakiman), Pasal 1 angka 8 menjelaskan :

“Pengadilan Khusus adalah pengadilan yang mempunyai kewenangan untuk memeriksa, mengadili dan memutus perkara tertentu yang hanya dapat 
dibentuk dalam salah satu lingkungan badan peradilan yang berada di bawah Mahkamah Agung yang diatur dalam undang-undang".

Norma tersebut dalam kaidah perundang-undangan telah dirumuskan secara lex stricta (jelas dan ketat) dan lex certa (tidak multitafsir), artinya dasar pengaturan pembentukan pengadilan khusus harus melalui undang-undang. ${ }^{2}$

Pilihannya kemudian apakah pengadilan khusus Pilkada akan diatur dalam undang-undang tersendiri atau disisipkan kedalam Undang-Undang Pilkada yang sudah ada saat ini ? Melihat kompleksitas UU Pilkada saat ini yang telah beberapa kali mengalami perubahan, dan substansinya hanya menyangkut hal-hal teknis penyelenggaraan Pilkada, maka akan tepat jika dasar hukum pembentukan pengadilan khusus Pilkada diatur dalam undang-undang tersendiri.

Pengadilan khusus yang sudah ada saat ini juga diatur dalam undang-undang tersendiri, sebut saja Undang-Undang Nomor 46 Tahun 2009 Tentang Pengadilan Tindak Pidana Korupsi (UU Pengadilan Tipikor), Undang-Undang Nomor 26 Tahun 2000 Tentang Pengadilan Hak Asasi Manusia dan Undang-Undang Nomor 14 Tahun 2002 tentang Pengadilan Pajak. Pertimbangan lain kenapa undangundang pengadilan khusus Pilkada harus terpisah dari UU Pilkada, agar rumusan aturannya lebih substantif dan fokus pada pembahasan pengadilan khusus Pilkada. Selain itu dasar argumentasi pemisahan UU pengadilan khusus pilkada dengan

2 Baca juga ketentuan Pasal 27 ayat (2) UndangUndang Nomor 48 Tahun 2009.
UU Pilkada adalah untuk memudahkan penyusunan Rancangan Undang-Undang (RUU) pengadilan khusus Pilkada. RUU pengadilan khusus Pilkada ini harus sudah masuk program legislasi nasional prioritas pada tahun 2019 setelah pemilu legislatif dan pemilihan presiden selesai digelar. RUU pengadilan khusus Pilkada setidaktidaknya harus memuat kedudukan dan yurisdiksi pengadilan, kompetensi absolut pengadilan, susunan pengadilan, mekanisme persidangan dan pembiayaan.

Dengan diaturnya pengadilan khusus Pilkada dalam undang-undang tersendiri yang kewenangannya berbeda dengan mandat sebagaimana dimaksud Pasal 157 ayat (1) UU Pilkada, maka yang perlu dilakukan oleh pembentuk undangundang (wetgever/legislator) adalah merevisi norma Pasal 157 ayat (1) UU Pilkada yang mulanya berbunyi:

"Perkara perselisihan hasil pemilihan diperiksa dan diadili oleh badan peradilan khusus".

Menjadi:

"Sengketa yang timbul selama tahapan penyelenggaraan Pilkada diperiksa dan diadili oleh badan peradilan khusus yang diatur dalam undang-undang".

Pandangan Penulis tersebut sejalan dengan ketentuan Pasal 10 ayat (1) Undang-Undang Nomor 12 Tahun 2011 tentang Pembentukan Peraturan Perundang-Undangan, yang menyebutkan bahwa salah satu muatan yang harus diatur melalui undang-undang adalah perintah suatu undang-undang untuk diatur dengan undang-undang.

Terkait desain kelembagaan pengadilan khusus Pilkada, merujuk 
Pasal 1 angka 8 dan Pasal 27 ayat (1) UU Kekuasaan Kehakiman, menyaratkan bahwa pengadilan khusus hanya dapat dibentuk dalam salah satu lingkungan peradilan yang berada dibawah Mahkamah Agung. Saat ini ada empat badan peradilan yang berada dibawah Mahkamah Agung yaitu, peradilan umum, peradilan agama, peradilan militer dan peradilan tata usaha negara.

Memperhatikan kompleksitas sengketa yang akan ditangani oleh pengadilan khusus Pilkada, diantaranya sengketa tata usaha negara, tindak pidana pemilihan dan sengketa perkara perselisihan hasil pemilihan (PHP), maka alternatif yang ideal adalah menyatuatapkan atau mengintegrasikan penanganan seluruh sengketa Pilkada tersebut melalui pengadilan khusus Pilkada dan meletakan kedudukannya berada dibawah lingkungan peradilan umum.

Mengingat Pilkada pada tahun 2024 didesain serentak secara nasional, maka penyatuatapan tersebut dimaksudkan agar penanganan sengketa Pilkada terintegrasi pada satu pengadilan khusus, dengan terintegrasinya penanganan sengketa Pilkada, maka dapat mengefektifkan waktu penyelesaian perkara. Selain itu penyatuatapan penanganan sengketa Pilkada ini diharapkan mampu menghadirkan putusan yang tidak hanya demokratis-prosedural tetapi juga berkeadilan.

Pengadilan khusus Pilkada yang berada dibawah lingkungan peradilan umum didesain memiliki tiga majelis khusus, diantaranya Majelis Khusus Sengketa Tata Usaha Negara, Majelis Khusus Tindak Pidana dan Majelis Khusus Perselisihan Hasil Pemilihan (PHP). Ketiga majelis khusus tersebut masing-masing memiliki kewenangan untuk memeriksa, mengadili dan memutus sengketa tata usaha negara pemilihan, tindak pidana pemilihan dan perkara perselisihan hasil pemilihan.

Terkait komposisi hakim pada pengadilan khusus Pilkada, akan terdiri dari dua orang hakim karir dan satu orang hakim ad hoc, yang berasal dari akademisi atau praktisi hukum yang menguasai hukum Kepemiluan. ${ }^{3}$

Argumentasi Penulis tersebut mengamini gagasan sebelumnya yang pernah disampaikan oleh Dian Agung Wicaksono (2015) yang berpendapat bahwa pengadilan khusus Pilkada terdiri dari dua orang hakim karir dan satu orang akademisi hukum. Pandangan Dian Agung Wicaksono (2015) yang menginginkan adanya hakim yang berasal dari akademisi hukum, adalah untuk memberikan perspektif yang memperkaya kualitas putusan dalam mengadili sengketa Pilkada.

Pengangkatan hakim ad hoc nantinya dapat dilakukan oleh sebuah panitia seleksi (Pansel) yang didalamnya terdiri dari unsur Mahkamah Agung, Komisi Pemilihan Umum (KPU) dan Badan Pengawas Pemilu (Bawaslu) serta unsur masyarakat. 
Sedangkan hakim karir pada pengadilan khusus Pilkada nantinya ditetapkan oleh Ketua Mahkamah Agung dan selama menjalankan tugasnya sebagai hakim pada pengadilan khusus Pilkada, hakim tersebut dibebaskan dari tugas kesehariannya sebagai hakim pada pengadilan asalnya.

Khusus pengangkatan hakim karir pada majelis khusus tata usaha negara pengadilan khusus Pilkada, Ketua Mahkamah Agung harus memperhatikan asal institusi peradilan hakim yang bersangkutan. Hakim karir pada majelis khusus tata usaha negara harus berasal dari Pengadilan Tata Usaha Negara dan/ atau Pengadilan Tinggi Tata Usaha negara. Pengadilan khusus Pilkada juga didesain sebagai pengadilan tetap, tidak bersifat temporer (ad hoc), dengan demikian Mahkamah Agung tidak perlu mengeluarkan peraturan terkait pembentukan pengadilan khusus Pilkada setiap menjelang diselenggarakannya Pilkada serentak, cukup diatur dalam undang-undang pengadilan khusus Pilkada.

Pengadilan khusus Pilkada nantinya didesain sebagai pengadilan pertama dan terakhir yang putusannya bersifat final dan mengikat (final and binding).

\section{Desain Kewenangan dan Yurisdiksi Pengadilan}

Kebijakan formulasi dan institusionalisasi peradilan juga harus memperhatikan desain kewenangan dan desain yurisdiksi pengadilan. Dalam doktrin ilmu hukum kedua hal tersebut dikenal dengan sebutan kompetensi absolut dan kompetensi relatif.

Kompetensi absolut adalah kewenangan mengadili perkara dari suatu pengadilan berdasar pada kewenangan atau beban tugas yang ditetapkan oleh undang-undang, sedangkan kompetensi relatif merupakan kewenangan mengadili perkara dari suatu pengadilan berdasarkan pada daerah hukum atau yurisdiksi peradilan (Abdulkadir Muhammad, 2005).

Pengadilan khusus Pilkada didesain sebagai lembaga adjudikasi yang mempunyai kompetensi absolut untuk memeriksa, mengadili dan memutus seluruh sengketa yang timbul selama proses penyelenggaraan Pilkada, yaitu tindak pidana pemilihan, sengketa tata usaha negara dan sengketa perselisihan hasil pemilihan.

Terkait mekanisme hukum acara pada pengadilan khusus Pilkada dapat diilustrasikan sebagai berikut:

\section{a. Tindak Pidana Pemilihan}

Penanganan tindak pidana pemilihan dari mulai pelaporan sampai penyidikan tetap mempertahankan desain yang saat ini diatur dalam UU Pilkada, yaitu melalui Sentra Penegakan Hukum Terpadu (Gakumdu) yang merupakan gabungan dari tiga institusi, Bawaslu Provinsi, dan/ atau Panwas Kabupaten/Kota, Kepolisian Daerah dan/atau Kepolisian Resor, dan Kejaksaan Tinggi dan/atau Kejaksaan Negeri. ${ }^{4}$

Setelah penyidikan selesai dan berkas perkara dinyatakan lengkap, Jaksa Penuntut Umum melimpahkan berkas perkara kepada pengadilan khusus Pilkada, selanjutnya majelis khusus tindak pidana pada pengadilan khusus Pilkada memeriksa mengadili dan memutus tindak pidana pemilihan.

4 Lebih lanjut Vide Pasal 152 ayat (1) UU Pilkada. 


\section{b. Sengketa Tata Usaha negara Pemilihan}

Sengketa tata usaha negara timbul sebagai akibat dikeluarkannya keputusan penyelenggara negara yang merugikan salah satu peserta pemilihan (pasangan calon). Pasangan calon yang merasa dirugikan oleh keputusan penyelenggara pemilihan in casu Putusan Komisi Pemilihan Umum (KPU) Provinsi atau KPU Kabupaten/Kota mengajukan keberatan kepada Bawaslu Provinsi atau Bawaslu Kabupaten/Kota.

Bawaslu Provinsi atau Bawaslu Kabupaten/Kota menggelar musyawarah administratif mempertemukan pasangan calon dengan KPU Provinsi /KPU Kabupaten/Kota. Apabila musyawarah administratif tersebut tidak tercapai kesepakatan, pasangan calon mengajukan gugatan ke pengadilan khusus Pilkada. Selanjutnya perkara tersebut diperiksa, diadili dan diputus oleh pengadilan khusus Pilkada melalui majelis khusus tata usaha negara.

\section{c. Perkara Perselisihan Hasil Pemilihan}

Perselisihan hasil pemilihan muncul disebabkan ketidakpuasan atas hasil rekapitulasi penghitungan suara yang dilakukan oleh KPU Provinsi atau KPU Kabupaten/Kota. Pasangan calon yang tidak menerima hasil rekapitulasi penghitungan suara tersebut dapat mengajukan gugatan ke pengadilan khusus Pilkada dengan dilengkapi buktibukti yang mendukung gugatannya.

Majelis khusus perselisihan hasil pemilihan pada Pengadilan khusus Pilkada memeriksa, mengadili dan memutus gugatan perselisihan hasil pemilihan tersebut.
Perubahan mekanisme penyelesaian perselisihan hasil pemilihan melalui pengadilan khusus ini harus disertai penghapusan Pasal 158 ayat (1) UU Pilkada yang mengatur syarat formil selisih suara yang dapat diajukan gugatan yaitu rentang 0,5 - 2,0\% (persen) disesuaikan dengan jumlah penduduk. Syarat formil tersebut sesungguhnya telah menyandera hak konstitusional seseorang dan berorientasi pada penegakkan hukum yang legalistik - formalistik. Selain itu syarat formil yang ada dalam pasal a quo menabrak asas ius curia novit yang telah termanifestasi dalam Pasal 10 ayat (1) Undang-Undang Nomor 48 Tahun 2009 tentang Kekuasaan Kehakiman.

Selain memiliki tiga kompetensi absolut seperti yang telah disampaikan diatas, pengadilan khusus Pilkada juga didesain memiliki kewenangan untuk memeriksa, mengadili dan memutus pelanggaran administrasi pemilihan.

Kualifikasi norma pelanggaran administrasi pemilihan pada UU Pilkada dirumuskan secara restriktif hanya menyangkut pelanggaran terhadap Pasal 73 ayat $(2)^{5}$, dengan syarat pelanggaran tersebut dilakukan secara Terstruktur, Sistematis dan Masif (TSM).

Terkait penyelesaian pelanggaran administrasi pemilihan, Bawaslu Provinsi atau Bawaslu Kabupaten/Kota berwenang

Pasal 73 ayat (1) UU Pilkada : "Calon dan/ atau tim Kampanye dilarang menjanjikan dan/atau memberikan uang atau materi lainnya untuk mempengaruhi penyelenggara Pemilihan dan/atau Pemilih". ayat (2) :

"Calon yang terbukti melakukan pelanggaran sebagaimana dimaksud pada ayat (1) berdasarkan putusan Bawaslu Provinsi dapat dikenai sanksi administrasi pembatalan sebagai pasangan calon oleh KPU Provinsi atau KPU Kabupaten/Kota." 
menerima, memeriksa dan memutus pelanggaran administrasi pemilihan. Dalam hal putusan Bawaslu Provinsi atau Bawaslu Kabupaten/Kota memerintahkan untuk membatalkan pasangan calon yang terbukti melanggar undang-undang, maka KPU Provinsi atau KPU Kabupaten/ Kota menerbitkan keputusan pembatalan terhadap pasangan calon dimaksud.

Pasangan calon yang dikenakan sanksi administrasi pembatalan dapat mengajukan upaya hukum ke pengadilan khusus Pilkada. Majelis khusus tata usaha negara pada Pengadilan khusus Pilkada memeriksa, mengadili dan memutus perkara tersebut.

Pertimbangan Penulis menempatkan pelanggaran administrasi diperiksa dan diadili oleh majelis khusus tata usaha negara pada pengadilan khusus Pilkada, karena yang menjadi objectum litis sengketanya adalah keputusan KPU Provinsi atau KPU Kabupaten/ Kota tentang pembatalan calon yang merupakan bagian dari putusan tata usaha negara.

Hal penting lain dalam upaya menemukan desain baku pengadilan khusus Pilkada adalah menyangkut kompetensi relatif atau yurisdiksi pengadilan. Pengadilan khusus Pilkada didesain berada pada Pengadilan negeri untuk pengadilan khusus pemilihan Bupati/Wali Kota dan untuk pengadilan khusus pemilihan Gubernur melekat pada Pengadilan Tinggi. Desain tersebut diharapkan dapat tercapai efisiensi penyelesaian perkara mengingat tuntutan waktu penyelesaian sengketa Pilkada yang relatif singkat, selain itu desain tersebut juga diharapkan dapat mewujudkan putusan yang demokratis dan berkeadilan.

\subsection{Keunggulan Badan Peradilan Khusus Pilkada}

Konsep pengadilan khusus Pilkada yang Penulis tawarkan memiliki beberapa keunggulan, antara lain:

1. Dasar pengaturan pengadilan khusus Pilkada tidak perlu diatur pada level Undang-Undang Dasar 1945, cukup diatur dalam undang-undang.

2. Seluruh sengketa yang timbul selama proses Pilkada diadili dalam satu peradilan, tidak terpisah-pisah seperti yang dipraktekan dewasa ini.

3. Penyatuatapan lembaga adjudikasi sengketa Pilkada melalui pengadilan khusus menghindarkan pengadilan mengadili sengketa yang bukan kewenangannya.

4. Efisiensi waktu penyelesaian sengketa, karena pengadilan khusus Pilkada didesain sebagai lembaga terkahir pengadil sengketa Pilkada.

5. Pemilihan satu orang hakim ad hoc sebagai hakim pada pengadilan khusus Pilkada akan memperkaya kualitas putusan.

6. Penempatan pengadilan khusus Pilkada berada dibawah lingkup peradilan umum akan memudahkan menginventarisir instrumen-instrumen yang dibutuhkan pengadilan.

7. Khusus penyelesaian sengketa Perselisihan Hasil Pemilihan (PHP), pengajuan gugatan tidak menyaratkan selisih suara, selama ditemukan cukup bukti telah terjadi pelanggaran terhadap ketentuan UU Pilkada, maka pengadilan wajib memeriksa, mengadili dan memutus sengketa PHP tersebut.

8. Intergasi penyelesaian seluruh sengketa pada pengadilan khusus Pilkada merupakan hal baru dalam 
praktek peradilan di Indonesia, sehingga gagasan pembentukan pengadilan khusus Pilkada ini diharapkan menjadi bagian dari pembaharuan hukum kepemiluan (electoral law reform) di Indonesia.

\section{Simpulan}

Dari penjelasan yang telah disampaikan dimuka, dapat disimpulkan beberapa hal, antara lain:

- Pengadilan khusus Pilkada didesain sebagai lembaga adjudikasi permanen, berkedudukan dibawah Mahkamah Agung yang yurisdiksi peradilannya meliputi, Pengadilan Tinggi untuk pengadilan khusus pemilihan Gubernur dan Pengadilan Negeri untuk pengadilan khusus pemilihan Bupati/Wali Kota. Kewenangan pengadilan khusus Pilkada tersebut yaitu memeriksa, mengadili dan memutus seluruh sengketa yang timbul selama proses Pilkada, yaitu sengketa tata usaha negara pemilihan, tindak pidana pemilihan, perselisihan hasil pemilihan dan pelanggaran administrasi pemilihan. Pengadilan khusus Pilkada nantinya memiliki tiga majelis, meliputi majelis khusus sengketa tata usaha negara untuk menggantikan pengadilan tata usaha negara, majelis khusus tindak pidana dan majelis khusus perselisihan hasil pemilihan. Terkait komposisi hakim akan diisi oleh hakim karir dan hakim ad hoc yang menguasai hukum kepemiluan. Pengadilan khusus Pilkada disetiap yurisdiksinya didesain sebagai lembaga peradilan pertama dan terakhir yang putusannya bersifat final dan mengikat.
- Gagasan pengadilan khusus Pilkada yang Penulis tawarkan mempunyai beberapa keunggulan, salah satunya adalah kewenangan pengadilan khusus Pilkada mengintegrasikan penanganan seluruh sengketa yang timbul selama proses penyelenggaraan Pilkada. selain itu intergasi penyelesaian seluruh sengketa pada pengadilan khusus Pilkada merupakan hal baru dalam praktek peradilan di Indonesia, sehingga gagasan pembentukan pengadilan khusus Pilkada ini diharapkan menjadi bagian dari pembaharuan hukum kepemiluan (electoral law reform) di Indonesia.

Memperhatikan keseluruhan substansi pada penelitian ini, Penulis merekomendasikan beberapa hal, yaitu:

- Pembentukan pengadilan khusus Pilkada harus segera diinisiasi oleh Dewan Perwakilan Rakyat (DPR) bersama Presiden, hal tersebut sebagai bentuk pengejawantahan mandat UU Pilkada, sehingga gagasan pembentukan pengadilan khusus Pilkada tidak hanya sebatas wacana yuridis tetapi terimplementasi menjadi legal praktis.

- Dalam merumuskan konsep kelembagaan pengadilan khusus Pilkada, pembentuk undangundang (wetgever/legislator) harus memperhatikan aspek independensi, kemandirian dan imparsialitas, agar tujuan akhir mewujudkan penyelesaian sengketa Pilkada yang demokratis dan berkeadilan dapat terwujud. 


\section{DAFTAR PUSTAKA}

Harun, R. (2016). Rekonstruksi Kewenangan Penyelesaian Perselisihan Hasil Pemilihan Umum. Jurnal Konstitusi, Volume 13, Nomor 1, Maret 2016, hlm. 14-15. Marzuki, P. M. (2010). Penelitian Hukum, Cetakan ke-6. Jakarta : Prenada Media. Muhammad, A. (2005). Hukum acara perdata Indonesia. Bandung : Citra Aditya Bakti. Prihatmoko, J. J. (2005). Pemilihan Kepala Daerah Langsung, Filosofi, Sitsem, dan Problem Penerapan di Indonesia. Yogyakarta: Pustaka Pelajar.

Soekanto, S., \& Mamudji, S. (2003). Penelitian Hukum Normatif Suatu Tinjauan Singkat. Cet. VII. Jakarta : PT Raja Grafindo Persada.

Suyatno. (2016). Pemilihan Kepala Daerah (Pilkada) dan Tantangan Demokrasi Lokal di Indonesia. Jurnal Politik Indonesia, Universitas Negeri Semarang, Volume 1 No. 2, hlm. 225. https://journal.unnes.ac.id/nju/index.php/jpi/article/ view/6586/4951.

Wicaksono, D., A., \& Ayutama, Anisa. (2015) Inisiasi Pengadilan Khsusus Pemilihan Kepala Daerah Dalam Menghadapi Keserentakan Pemilihan Gubernur, Bupati dan Walikota di Indonesia. Jurnal Rechtsvinding, Volume 4, Nomor 1, hlm. 174.

Zoelva, H. (2013). Aspek Konstitusionalitas Pengadilan Khusus di Indonesia. Dalam Hermansah, dkk (Ed). Putih Hitam Pengadilan Khusus. (hlm. 171). Jakarta : Sekretariat Jenderal Komisi Yudisial.

Zuhro, S. (2012). Memahami Demokrasi Lokal: Pilkada, Tantangan dan Prospeknya. Jurnal Pemilu dan Demokrasi, Volume 4, Desember 2012, hlm. 30-31.

Undang-Undang Dasar Negara Republik Indonesia Tahun 1945.

Undang Nomor 48 Tahun 2009 tentang Kekuasaan Kehakiman.

Undang-Undang Nomor 12 Tahun 2011 tentang Pembentukan Peraturan PerundangUndangan.

Undang-Undang Nomor 10 Tahun 2016 tentang Perubahan Kedua Atas Undang-Undang Nomor 1 Tahun 2015 Tentang Penetapan Peraturan Pemerintah Pengganti Undang-Undang Nomor 1 Tahun 2014 Tentang Pemilihan Gubernur, Bupati, dan Walikota Menjadi Undang-Undang. 
42 Jurnal Adhyasta Pemilu 